\title{
Kompleksitas Perusahaan, Client Importance dan Volatilitas Idiosinkratik
}

\author{
Mei Rinta ${ }^{1}$ \\ Fakultas Ekonomi dan Bisnis \\ Universitas Airlangga, Indonesia
}

\begin{abstract}
Surel : mei.rinta@gmail.com
ABSTRAK

Kajian ini menguji adanya pengaruh antara kompleksitas perusahaan dan client importance terhadap volatilitas idiosinkratik. Sampel penelitian adalah perusahaan emiten semua industri kecuali jasa keuangan dan perbankan periode 2014-2018. Variabel tergantung adalah volatilitas idiosinkratik, sedangkan variabel bebas kompleksitas perusahaan dan client importance. Regresi linier berganda digunakan untuk menguji. Hasil memperlihatkan adanya pengaruh positif yang signifikan client importance terhadap variabel tergantung dan pengaruh negatif yang signifikan kompleksitas perusahaan terhadap variabel tergantung. Ini berarti informasi lini bisnis dan faktor terkait auditor menjadi signal bagi investor untuk bereaksi atas saham perusahaan.
\end{abstract}

Kata Kunci: Kompleksitas Perusahaan; Client Importance; Volatilitas Idiosinkratik.

\section{Company Complexity, Client Importance and Idiosyncratic Volatility}

\begin{abstract}
This study examines the influence between company complexity and client importance on idiosyncratic volatility. The research sample are listed companies in all industries except financial services and banking for period 2014-2018. The dependent variable is idiosyncratic volatility, while the independent variable is company complexity and client importance. Multiple linear regression was used to test. The results showed that there was a significant positive effect of client importance on the dependent variable and a significant negative effect on company complexity on the dependent variable. This means that business line information and auditor-related factors are a signal for investors to react to company shares.
\end{abstract}

Keywords: Complexity Of The Company; Client Importance; Idiosyncratic Volatility.

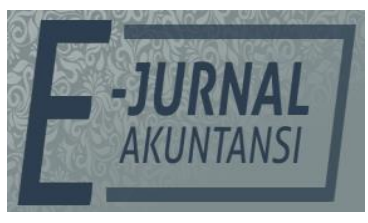

e-ISSN 2302-8556

Vol. 31 No. 9

Denpasar, September 2021 Hal. 2289-2300

DOI:

10.24843/EJA.2021.v31.i09.p11

PENGUTIPAN: Rinta, M. (2021). Kompleksitas Perusahaan, Client Importance dan Volatilitas Idiosinkratik. EJurnal Akuntansi, 31(9), 2289-

2300

RIWAYAT ARTIKEL: Artikel Masuk: 4 Mei 2021

Artikel Diterima: 25 Agustus 2021

Artikel dapat diakses : https://ojs.unud.ac.id/index.php/Akuntansi/index 


\section{PENDAHULUAN}

Telah disebutkan dalam undang-undang pasar modal bahwa perusahaan yang mendaftar sebagai perusahaan terbuka wajib memenuhi prinsip keterbukaan dengan cara menyampaikan informasi mengenai kegiatan usahanya bagi masyarakat. Keputusan investasi telah dilakukan melalui serangkaian analisis. Seringkali investor memilih saham sebagai instrumen keuangan dalam membuat keputusan investasinya, oleh karena itu informasi spesifik perusahaan dibutuhkan investor dalam memahami pelaporan keuangan.

Informasi spesifik perusahaan dapat berupa informasi publik maupun informasi pribadi (private) (Ferreira dan Laux, 2007), (Hutton et al., 2009), (Kwan, 1996), dan ( $\mathrm{Su}$ et al., 2016). Informasi publik merupakan informasi yang dipublikasikan dalam pelaporan keuangan secara langsung ke dalam harga saham, sedangkan informasi pribadi (private) merupakan informasi yang dimasukkan ke dalam harga melalui perdagangan informasi (Su et al., 2016). Harga saham mencerminkan informasi publik perusahaan dan informasi pribadi (private) tentang fundamental perusahaan (Chen et al., 2006) dan (Morck et al., 2000).

Informasi yang diterima investor harus relevan dan akurat yang mencerminkan keadaan usaha perusahaan yang sebenarnya. Informasi yang tidak akurat akan mendorong investor dalam melakukan kesalahan spekulasi yang akan menyebabkan kerugian. Informasi direpresentasikan melalui harga saham. Menurut teori efficient market hypothesis bentuk kuat yang dikemukakan oleh Fama (1970), harga saham merefleksikan informasi dahulu, saat ini dan akan datang agar dapat dikatakan efisien, artinya ada keterkaitan antara harga saham dan informasi. Pasar saham menyesuaikan diri dengan penerimaan informasi baru dan mencerminkan dengan cara yang rasional semua informasi yang relevan mengenai saham dan ekonomi secara keseluruhan (Malkiel, 1989).

Pergerakan harga saham mencerminkan perubahan dalam faktor fundamental yang mendasari nilai-nilai saham (Haggard et al., 2008). Pergerakan harga saham yang tidak dapat diprediksi umumnya disebabkan oleh pergerakan tak terduga dalam faktor-faktor ekonomi, perubahan tak terduga di lingkungan pasar perusahaan misalnya informasi industri, dan peristiwa tak terduga yang berasal dari perusahaan itu sendiri (Roll, 1988). Efisiensi didorong oleh informasi spesifik perusahaan yang dibagikan kepada publik.

Volatilitas idiosinkratik harga saham yang lebih tinggi menyampaikan lebih banyak informasi spesifik perusahaan ke pasar keuangan (Su et al., 2016), yang memungkinkan investor untuk membuat keputusan keuangan lebih baik yang mengarah pada alokasi modal yang efisien (Durnev et al., 2004) dan (Wurgler, 2000). Beberapa studi memperdebatkan tentang apakah volatilitas idiosinkratik yang lebih tinggi berarti lebih banyak atau lebih sedikit informasi dalam harga saham. Morck et al. (2000) membandingkan volatilitas idiosinkratik di berbagai negara dan menemukan bahwa perusahaan-perusahaan di negara-negara maju memiliki volatilitas idiosinkratik lebih tinggi daripada negara-negara berkembang.

Menurut Markowitz (1952), Sharpe (1964) dan Lintner (1965) total risiko portofolio aset merupakan perpaduan dari systematic dan unsystematic risk. Volatilitas idiosinkratik adalah risiko yang tidak berkorelasi dengan pergerakan 
harga sistematis di pasar (Tan \& Liu, 2016). Umumnya risiko ini tidak dipengaruhi oleh kondisi makro namun dipengaruhi oleh karakteristik dari perusahaan. Budaya dan perilaku perusahaan memiliki pengaruh besar pada bagaimana perilaku investor di pasar dan pergerakan harga saham yang dihasilkan perusahaan (Ferreira \& Laux, 2007). Ketika perusahaan diketahui menyelewengkan sejumlah dana atau diketahui menutupi informasi atau fakta material di laporan keuangannya oleh publik, maka memicu reaksi dari investor untuk menjual sahamnya. Hal ini akan menyebabkan tingginya penawaran saham di pasar sehingga harga saham perusahaan tersebut mengalami penurunan. Sebaliknya ketika kinerja perusahaan bagus dan memiliki tata kelola perusahaan yang baik, maka memicu reaksi dari investor untuk membeli sahamnya, menyebabkan rendahnya penawaran saham di pasar sehingga ada peningkatan harga.

Kenaikan nilai suatu saham dapat didorong oleh tempat terjadinya penawaran dan permintaan informasi (Veldkamp, 2006). Ketika informasi spesifik perusahaan tidak tersedia, investor mengandalkan sinyal informasi umum (dan murah) seperti berita tingkat pasar dan industri untuk menduga arus kas suatu perusahaan. Ketergantungan pada sinyal umum seperti itu berkontribusi pada kenaikan harga saham yang lebih besar dan menurunkan tingkat informasi harga saham (Haggard et al., 2008) dan (Jin \& Myers, 2006). Sinyal informasi umum yang mudah didapatkan adalah informasi mengenai kompleksitas perusahaan seperti segmen perusahaan dan terkait dengan tingkat fee audit yang mencerminkan seberapa ketergantungan auditor pada klien atau client importance Su et al. (2016).

Menurut Lee \& Liu (2011) komponen informasi dari volatilitas return idiosinkratik menurun dan kemudian meningkat dengan keinformatifan harga disebabkan lebih banyak investor memilih untuk menghasilkan informasi dan lebih banyak informasi dimasukkan ke dalam harga saham, sehingga keinformatifan harga saham meningkat. Pada gilirannya, meningkatkan informasi dari volatilitas return idiosinkratik karena semakin banyak informasi yang tercermin dalam harga, semakin sedikit ketidakpastian tentang nilai saham, dan ketidakpastian dari volatilitas return idiosinkratik menjadi lebih kecil. Oleh karena itu, informasi meningkat dengan keinformatifan harga sedangkan ketidakpastian berkurang dengan keinformatifan harga. Ini terjadi ketika varians permintaan dari pedagang likuiditas (liquidity traders) relatif besar dibandingkan dengan varians dalam nilai fundamental perusahaan. Rasionalitas investor dalam menilai suatu saham dilihat dari nilai saat ini dari return future cash flow didiskontokan menggunakan karakteristik risiko mereka. Ketika investor mempelajari sesuatu tentang fundamental, maka dengan singkat merespon berita baru (Shleifer, 2000).

Motivasi dilakukan penelitian ini karena belum banyak yang melakukan penelitian dengan menggunakan variabel dari aspek perusahaan terutama terkait dengan informasi lini perusahaan seperti kompleksitas perusahaan dan dari aspek auditor yaitu client importance dalam kaitannya dengan volatilitas idiosinkratik harga saham yang merefleksikan jumlah informasi spesifik perusahaan di Indonesia. Memahami volatilitas idiosinkratik penting karena volatilitas idiosinkratik merupakan komponen dari volatilitas total yang diperlukan untuk menilai options dan derivatives lainnya serta dapat memahami faktor penentu variasi volatilitas yang membantu menciptakan model penetapan harga opsi yang 
lebih baik. Penelitian ini memiliki implikasi untuk bursa, profesi akuntansi dan kontribusi khususnya bagi entitas, investor dan regulator. Bagi perusahaan, hasil kajian memotivasi jumlah informasi spesifik perusahaan di laporan keuangan sehingga mendorong informasi yang transparan. Bagi investor, kajian ini dapat memperkaya informasi spesifik perusahaan di laporan keuangan yang mempengaruhi volatilitas idiosinkratik harga saham dalam mempertimbangkan investasi. Bagi regulator, hasil penelitian ini dapat mendorong peningkatan transparansi pasar dan perolehan informasi yang relevan.

Fama (1970) mengemukakan dalam teori Efficient Market Hypothesis bahwa efisiensi menggambarkan semua informasi dan bereaksi terhadap adanya informasi. Ini artinya nilai saham mencerminkan informasi dahulu, saat ini dan akan datang. Ketika keinformatifan suatu berita meningkat, spekulan akan lebih agresif karena spekulan mengharapkan berita lebih menggerakkan harga, yang menghasilkan keuntungan lebih besar dari berspekulasi pada pergerakan harga jangka pendek (Foucault et al., 2016). Dengan demikian, volume perdagangan semakin meningkat dan spekulan menyumbang porsi volume perdagangan yang lebih besar dan harga saham secara langsung berhubungan dengan kepuasan pemegang saham (investor) yang pada gilirannya dapat mempengaruhi perilaku perdagangan investor dan volatilitas idiosinkratik yang dihasilkan (Tan \& Liu, 2016). Gambar 1, menunjukkan rancangan kajian dari penelitian ini.

Variabel Independen

1. Kompleksitas Perusahaan $\left(\mathrm{X}_{1}\right)$

2. Client Importance $\left(\mathrm{X}_{2}\right)$

\begin{tabular}{|c|c|}
\hline Variabel Kontrol & Volatilitas Idiosinkratik \\
\hline $\begin{array}{l}\text { 1. Size } \\
\text { 2. Age }\end{array}$ & \\
\hline $\begin{array}{l}\text { 3. Leverage } \\
\text { 4. Loss }\end{array}$ & \\
\hline
\end{tabular}

Sumber: Data Penelitian, 2021

Gambar 1. Rancangan kajian

Segmen perusahaan adalah jumlah segmen yang dimiliki oleh perusahaan. Segmen perusahaan penting untuk diteliti karena pengungkapan informasi segmen perusahaan akan memberikan sinyal ke pasar (Ronen \& Livnat, 1981). Lobo et al. (1998) dalam penelitiannya menemukan ada variabilitas harga pada saat pertama kali pengungkapan informasi. Ini berarti informasi segmen menyampaikan informasi tambahan atas informasi lini bisnis perusahaan dan adanya reaksi harga saham yang signifikan pada saat rilis informasi lini bisnis.

Ramalan pendapatan yang dihasilkan oleh model statistik atau oleh analis, yang didasarkan pada data lini bisnis, lebih akurat daripada yang hanya didasarkan pada informasi keuangan konsolidasi (Baldwin, 1984) dan (Collins, 1976). Su et al. (2016) menunjukkan segmen perusahaan berhubungan negatif signifikan dengan volatilitas idiosinkratik harga saham artinya adanya peningkatan segmen perusahaan makin mendiversifikasi operasi maupun lokasi 
geografis sehingga banyak informasi yang tersedia untuk pasar, dengan demikian volatilitas idiosinkratik harga saham semakin kecil.

Pengungkapan informasi segmen perusahaan akan memberikan sinyal ke pasar (Ronen \& Livnat, 1981). Lobo et al. (1998) dalam penelitiannya menemukan ada variabilitas harga pada saat pertama kali pengungkapan informasi. Ini berarti informasi segmen menyampaikan informasi tambahan atas informasi lini bisnis perusahaan dan adanya reaksi harga saham yang signifikan pada saat rilis informasi lini bisnis. Su et al. (2016) menunjukkan bahwa segmen perusahaan berhubungan negatif signifikan dengan volatilitas idiosinkratik harga saham artinya banyaknya segmen membuat perusahaan semakin terdiversifikasi dalam masalah operasi maupun lokasi geografis sehingga banyak informasi yang tersedia untuk pasar yang akan mempengaruhi volatilitas idiosinkratik harga saham semakin kecil.

$\mathrm{H}_{1}$ : Ada pengaruh negatif segmen perusahaan terhadap volatilitas idiosinkratik harga saham.

Client importance adalah ketergantungan ekonomi terhadap klien oleh kantor akuntan publik. Fee yang dibayarkan oleh klien dapat mempengaruhi independensi auditor sehingga menyebabkan auditor seakan memiliki ketergantungan kepada kliennya. Lord (1992) menemukan kontribusi pendapatan relatif dari klien ke kantor akuntan publik mempengaruhi penerimaan auditor terhadap posisi pelaporan agresif klien. Client importance terkait dengan independensi auditor yang merupakan salah satu indikator dalam menentukan mutu jasa audit dan untuk meminimalisir adanya insentif keuangan serta sosial yang diterima oleh auditor.

Client importance secara tidak langsung terkait dengan harga saham. Su et al. (2016) memperlihatkan client importance berhubungan positif secara signifikan dengan volatilitas idiosinkratik harga saham artinya semakin kantor akuntan publik tergantung kepada klien tertentu akan menyebabkan kualitas audit semakin rendah dan investor yang mengambil informasi dari laporan keuangan yang diaudit akan menilai rendah perusahaan sehingga akan memicu reaksi harga saham dengan demikian volatilitas idiosinkratik harga saham menjadi lebih kecil. Fee yang dibayarkan oleh klien dapat mempengaruhi independensi auditor sehingga menyebabkan auditor seakan memiliki ketergantungan kepada kliennya. Lord (1992) menemukan kontribusi pendapatan relatif dari klien ke kantor akuntan publik mempengaruhi penerimaan auditor terhadap posisi pelaporan agresif klien. Client importance terkait dengan independensi auditor yang merupakan salah satu indikator dalam menentukan mutu jasa audit dan untuk meminimalisir adanya insentif keuangan serta sosial yang diterima oleh auditor. Client importance erat kaitannya dengan kualitas audit. Kualitas audit akan mempengaruhi konten informasi dari laporan akuntansi yang diaudit. Investor di pasar modal mengambil informasi dari laporan akuntansi yang diaudit, memberi harga pada perusahaan, dan membuat keputusan investasi yang sesuai (Lu \& Sapra, 2009). Client importance secara tidak langsung terkait dengan harga saham. Su et al. (2016) memperlihatkan hasil client importance berhubungan positif secara signifikan dengan volatilitas idiosinkratik harga saham artinya semakin kantor akuntan publik tergantung kepada klien tertentu akan menyebabkan kualitas audit semakin rendah dan investor yang mengambil informasi dari laporan 
keuangan yang diaudit akan menilai rendah perusahaan sehingga akan memicu reaksi harga saham dengan demikian volatilitas idiosinkratik harga saham menjadi lebih kecil.

$\mathrm{H}_{2}$ : Ada pengaruh positif client importance terhadap volatilitas idiosinkratik harga saham.

\section{METODE PENELITIAN}

Kajian ini merupakan penelitian dengan pendekatan kuantitatif. Volatilitas idiosinkratik harga saham adalah besaran perubahan harga saham yang dipengaruhi oleh karakteristik dari perusahaan tersebut yang merefleksikan keinformatifan suatu harga saham. Volatilitas idiosinkratik harga saham diukur dengan menghitung logaritma dari volatilitas idiosinkratik yang didasarkan pada model pasar yang diperluas (dinotasikan sebagai SPIV) (Su et al., 2016). Model regresinya adalah.

$R_{i, w}=\alpha_{i}+\beta_{1, i}{ }^{*} r_{m, w-1}+\beta_{2, i}{ }^{*} r_{m, w}+\beta_{3, i}{ }^{*} r_{m, w+1}+\varepsilon_{i, w}$

Keterangan:

$R_{i, w} \quad=$ Return saham i dalam minggu $\mathrm{w}$

$r_{m, w-1}=$ Nilai tertimbang market return dalam minggu $\mathrm{w}-1$

$r_{m, w} \quad=$ Nilai tertimbang market return dalam minggu $\mathrm{w}$

$r_{m, w+1}=$ Nilai tertimbang market return dalam minggu $\mathrm{w}+1$

a $\quad$ Konstanta

$\beta \quad=$ Koefisien regresi

$\varepsilon \quad=$ Error estimate

Mengukur seberapa besar return saham individu bergerak bersama dengan market return, kemudian menghitung SPIV untuk saham i pada tahun fiskal $\mathrm{t}$ sebagai berikut (Su et al., 2016).

$S P I V_{i, t}=\log \left(\frac{1-R_{i, t}^{2}}{R_{i, t}^{2}}\right)$

Dimana $\mathrm{R}^{2} \mathrm{i}, \mathrm{diambil}$ dari model persamaan (1) dan mengukur kekuatan penjelas dari informasi pasar untuk return saham individu dari saham i pada tahun fiskal $\mathrm{t}$, sedangkan $1-\mathrm{R}^{2}, \mathrm{t}$ mengukur variasi spesifik perusahaan, atau volatilitas idiosinkratik. Volatilitas relatif diukur menggunakan logaritma natural dari rasio $1-\mathrm{R}_{\mathrm{i}, \mathrm{t}}$ dibagi dengan $\mathrm{R} 2_{\mathrm{i}, \mathrm{t}}$. Semakin tinggi nilai volatilitas idiosinkratik harga saham, semakin besar jumlah informasi spesifik perusahaan yang terkandung dalam harga saham. Segmen perusahaan adalah jumlah segmen yang dimiliki oleh perusahaan. Segmen perusahaan diukur dengan menghitung logaritma dari jumlah segmen bisnis/geografi yang dimiliki klien pada tahun $\mathrm{t}(\mathrm{Su}$ et al., 2016). Client importance adalah ketergantungan ekonomi terhadap klien oleh kantor akuntan publik. Client importance diukur dengan menghitung biaya jasa audit dari klien tertentu dibandingkan dengan jumlah keseluruhan biaya jasa audit suatu kantor akuntan publik pada tahun fiskal (Su et al., 2016). Sumber data penelitian menggunakan data historis saham mingguan dari yahoo finance dan laporan keuangan tahunan perusahaan selama periode 2014-2018 dari data pasar modal Indonesia. Populasinya adalah seluruh perusahaan terbuka di Bursa Efek Indonesia periode 2014-2018, sedangkan sampel dipilih berdasarkan kriteriakriteria antara lain merupakan emiten yang bergerak di semua industri kecuali 
jasa keuangan dan perbankan, mempublikasikan laporan keuangan tahunan di periode sampel, periode laporan keuangan perusahaan berakhir setiap 31 Desember, tersedia di www.idx.co.id untuk periode pengamatan selama periode 2014-2018, menerbitkan laporan keuangan auditan dalam satuan mata uang Rupiah, dan memiliki data yang diperlukan. Model analisis antara lain.

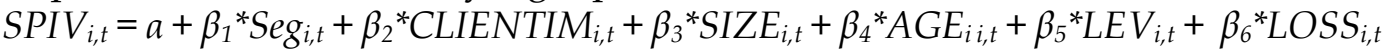

$$
\begin{aligned}
& +\varepsilon
\end{aligned}
$$

Data diolah menggunakan regresi linier berganda estimasi Ordinary Least Square (OLS).

\section{HASIL DAN PEMBAHASAN}

Kajian kompleksitas perusahaan dan client importance menggunakan observasi 297. Dari 297 observasi tersebut kemudian dilakukan perhitungan statistik deskriptif, korelasi Pearson dan analitis utama dengan uji regresi linier berganda dengan estimasi OLS (ordinary least square). Deskriptik statistik bertujuan untuk menampilkan nilai paling rendah, paling besar, rerata, dan simpangan baku masing-masing variabel independen dan dependen, serta kontrol. Berikut hasil selengkapnya.

\section{Tabel 1. Perhitungan Deskriptif Statistik}

\begin{tabular}{lccccc}
\hline Variabel & $\mathrm{N}$ & $\begin{array}{c}\text { Nilai paling } \\
\text { kecil }\end{array}$ & $\begin{array}{c}\text { Nilai paling } \\
\text { besar }\end{array}$ & Rerata & Simpangan baku \\
\hline SPIV & 297 & $-0,264$ & 2,703 & 0,939 & 0,455 \\
CLIENT & 297 & 0,003 & 1,000 & 0,174 & 0,246 \\
IM & & 0,000 & 3,258 & 1,070 & 0,540 \\
SEG & 297 & 25,042 & 32,959 & 29,123 & 1,495 \\
SIZE & 297 & 0,061 & 0,956 & 0,462 & 0,213 \\
LEV & 297 & 0 & 1 & 0,150 & 0,356 \\
LOSS & 297 & 3 & 67 & 17,060 & 9,341 \\
AGE & 297 & & & &
\end{tabular}

Sumber: Data Penelitian, 2021

Setelah dilakukan perhitungan dengan statistik deskriptif dilakukan perhitungan dengan menggunakan uji korelasi Pearson. Hasil selengkapnya tersaji pada Tabel 2 .

Tabel 2. Analisis Korelasi Bivariat

\begin{tabular}{lrrrrrr}
\hline & SPIV & CLIENTIM & SEG & SIZE & LEV & LOSS \\
\hline \multirow{2}{*}{ CLIENTIM } & $0,178^{* *}$ & & & & & \\
\multirow{2}{*}{ SEG } & 0,002 & & & & & \\
\multirow{2}{*}{ SIZE } & $-0,176^{* *}$ & 0,007 & & & & \\
& 0,002 & 0,910 & & & & \\
\multirow{2}{*}{ LEV } & $-0,341^{* *}$ & $-0,136^{*}$ & $0,224^{* *}$ & & & \\
\multirow{2}{*}{ LOSS } & 0,000 & 0,019 & 0,000 & & & \\
& 0,017 & $0,155^{* *}$ & $0,148^{*}$ & $0,148^{*}$ & & \\
\multirow{2}{*}{ AGE } & 0,773 & 0,008 & 0,011 & 0,011 & & \\
& $0,169^{* *}$ & $0,151^{* *}$ & $-0,039$ & $-0,141^{*}$ & $0,260^{* *}$ & \\
& 0,003 & 0,009 & 0,503 & 0,015 & 0,000 & \\
& $-0,112$ & $-0,110$ & $-0,005$ & $0,150^{* *}$ & 0,004 & $-0,039$ \\
& 0,054 & 0,059 & 0,927 & 0,009 & 0,940 & 0,500 \\
\hline
\end{tabular}

Sumber: Data Penelitian, 2021 
Regresi linier berganda digunakan untuk menguji karena variabel independen berjumlah lebih dari satu. Pertama-tama, terlebih dahulu dilakukan uji asumsi klasik. Uji Normalitas untuk mengetahui normalitas dilakukan uji non parametik Kolmogrov-smirnov. Jika signifikansi (2-tailed) menunjukan lebih dari 0,05 maka dikatakan berdistribusi normal.

\section{Tabel 3. Kolmogrov Smirnov}

\begin{tabular}{lr}
\hline & Unstandardized Residual \\
\hline Kolmogorov-Smirnov Z & 0,948 \\
Asymp. Sig. (2-tailed) & 0,330 \\
\hline
\end{tabular}

Sumber: Data Penelitian, 2021

Berdasarkan Tabel 3, nilai Kolmogrov-smirnov 0,948 dengan tingkat signifikansi 0,330 . Nilai signifikansi ini lebih dari 0,05 memperlihatkan data terdistribusi secara normal. Uji Multikolinieritas, hasil pengujian multikolinearitas dalam penelitian ini ditunjukkan dalam Tabel berikut ini.

\section{Tabel 4. Uji Multikolinieritas}

\begin{tabular}{lcc}
\hline & \multicolumn{2}{c}{ Collinearity Statistics } \\
\cline { 2 - 3 } & Tolerance & VIF \\
\hline CLIENTIM & 0,935 & 1,07 \\
SEG & 0,933 & 1,072 \\
SIZE & 0,871 & 1,148 \\
LEV & 0,865 & 1,156 \\
LOSS & 0,890 & 1,123 \\
AGE & 0,968 & 1,033 \\
\hline
\end{tabular}

Sumber: Data Penelitian, 2021

Semua variabel independen dan kontrol mempunyai nilai tolerance lebih dari 0,1 dan nilai VIF < 10 pada Tabel 4. Disimpulkan bahwa semua variabel baik independen maupun kontrol tidak terjadi Multikolinearitas. Uji Heterokedastisitas, uji gejala heteroskedastisitas dapat diketahui dengan menggunakan grafik plot (scatter plot). Jika titik-titik menyebar dan tidak membentuk pola yang khas maka uji regresi tidak terkena asumsi heteroskedastisitas dapat dilihat sebagai berikut.

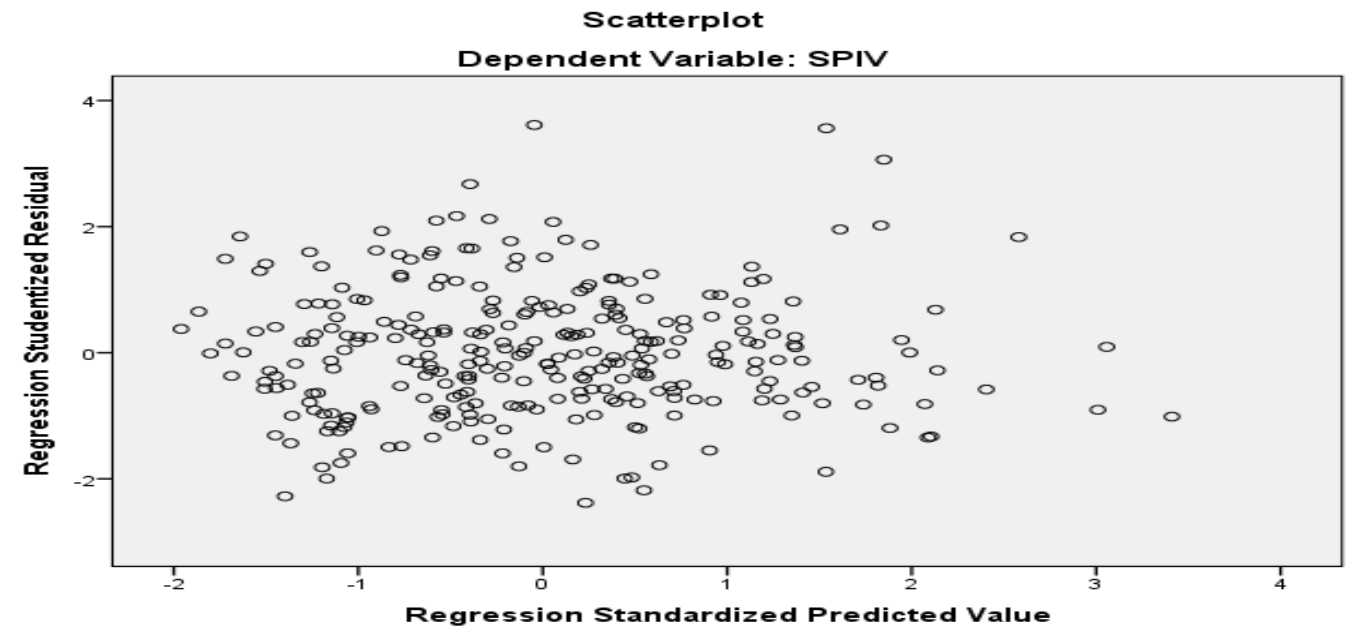

Gambar 2. Perhitungan Heterokedastisitas

Sumber: Data Penelitian, 2021 
Pada diagram scatterplot menunjukkan bahwa titik-titik menyebar dan tidak membentuk pola yang khas. Dapat disimpulkan terjadi gejala homoskedastisitas atau tidak terjadi hubungan antara variabel dependen dengan variabel independen, sehingga variabel dependen benar-benar hanya dijelaskan oleh variabel independen. Model regresi terbebas dari gejala heteroskedastisitas. Uji autokorelasi untuk menguji adanya korelasi antara pengganggu pada periode $t$ dengan pengganggu pada periode $\mathrm{t}-1$ (sebelumnya). Untuk mengetahuinya digunakan uji Durbin Watson. Pengujian dikatakan bebas bebas autokorelasi jika berada diantara dU- 4-dU.

Tabel 5. Uji Durbin - Watson

\begin{tabular}{ccrc}
\hline $\mathrm{dU}$ & $4-\mathrm{dU}$ & $\mathrm{DW}$ & Kesimpulan \\
\hline 1,819 & 2,181 & 1,811 & Bebas autokorelasi \\
\hline
\end{tabular}

Sumber: Data Penelitian, 2021

Tabel 5, memperlihatkan uji autokorelasi berada pada daerah bebas autokorelasi. Selanjutnya ringkasan hasil regresi linier berganda sebagai berikut.

\section{Tabel 6. Hasil Analisis Regresi Berganda}

\begin{tabular}{ccccc}
\hline \multirow{2}{*}{ Variabel Independen } & \multicolumn{4}{c}{ Model Regresi } \\
\cline { 2 - 5 } & Koefisien & $\mathrm{t}$ & Sig. & Kesimpulan \\
\hline Konstanta & 3,504 & 7,062 & 0,000 & \\
CLIENTIM & 0,212 & 2,064 & 0,040 & Ho ditolak \\
SEG & $-0,097$ & $-2,065$ & 0,040 & Ho ditolak \\
SIZE & $-0,086$ & $-4,897$ & 0,000 & \\
LEV & 0,070 & 0,569 & 0,570 & \\
LOSS & 0,124 & 1,698 & 0,090 & \\
AGE & $-0,003$ & $-0,987$ & 0,324 & \\
F statistic & & & 9,206 & \\
F Sig & & & 0,000 & \\
R & & & 0,160 & \\
\hline
\end{tabular}

Sumber: Data Penelitian, 2021

Pada Tabel 6, memperlihatkan client importance mempunyai pengaruh positif signifikan terhadap volatilitas idiosinkratik dengan nilai koefisien 0,212 dan signifikansi 0,040. Kompleksitas perusahaan mempunyai pengaruh negatif signifikan yaitu -0,097 dengan signifikansi 0,040. Ini berarti semakin tinggi client importance maka semakin tinggi pula volatilitas idiosinkratik. Sebaliknya pada segmen yang mencerminkan kompleksitas perusahaan, semakin tinggi kompleksitas perusahaan maka semakin rendah volatilitas idiosinkratik. Hasil perhitungan juga menunjukkan bahwa variabel kontrol yang signifikan adalah size dan kerugian (loss) pada level. Dalam menguji keberartian model digunakan uji $\mathrm{F}$, pada tahap ini pengujian menunjukkan tingkat signifikansi sebesar 0,000 atau lebih kecil daripada 0,05 bisa dikatakan bahwa pada tahap ini variabelvariabel independen yang diujikan secara simultan mempunyai pengaruh terhadap variabel dependen. Untuk leverage dan age tidak berdampak signifikan. 
Nilai signifikansi F yang diperoleh kurang dari 0,05 menunjukkan bahwa model telah fit atau sesuai.

Tabel 7. Uji Koefisien Determinasi

\begin{tabular}{ccc}
\hline $\mathrm{R}$ & $\mathrm{R}^{2}$ & Adjusted $\mathrm{R}^{2}$ \\
\hline $0,400^{\mathrm{a}}$ & 0,160 & 0,143 \\
\hline
\end{tabular}

Sumber: Data Penelitian, 2021

Seberapa besar seluruh prediktor dalam menjelaskan variabel dependennya ditunjukkan oleh koefisien determinasi $\left(R^{2}\right)$. Pada Tabel 7, nilai $R^{2}$ diperoleh 0,160 artinya client importance, kompleksitas perusahaan dan kontrol sanggup menerangkan perubahan volatilitas idiosinkratik sebesar 0,160 atau $16 \%$ sisanya 0,84 atau $84 \%$ dijelaskan oleh variabel diluar penelitian.

Hasil perhitungan regresi memperlihatkan kompleksitas perusahaan mempunyai pengaruh negatif signifikan yaitu -0,097 dengan signifikansi 0,040. Artinya tingginya kompleksitas perusahaan maka semakin rendah volatilitas idiosinkratik. Adanya pengaruh negatif kompleksitas perusahaan terhadap volatilitas idiosinkratik ini konsisten dengan Su et al. (2016) bahwa segmen perusahaan mempunyai hubungan negatif signifikan dengan volatilitas idiosinkratik harga saham artinya banyaknya segmen perusahaan maka semakin terdiversifikasi dalam operasi maupun lokasi geografis sehingga banyak informasi yang tersedia untuk pasar, dengan demikian volatilitas idiosinkratik harga saham semakin kecil.

Dampak segmen pada volatilitas ini dapat dijelaskan dengan argumen bahwa pengungkapan informasi segmen perusahaan akan memberikan sinyal ke pasar (Ronen \& Livnat, 1981). Informasi segmen menyampaikan informasi tambahan atas informasi lini bisnis perusahaan dan adanya reaksi harga saham yang signifikan pada saat rilis informasi lini bisnis. Ramalan pendapatan yang dihasilkan oleh model statistik atau oleh analis, yang didasarkan pada data lini bisnis, lebih akurat daripada yang hanya didasarkan pada informasi keuangan konsolidasi (Baldwin, 1984) dan (Collins, 1976). Informasi lini bisnis yang lebih penting menyebabkan investor bereaksi atas informasi lini bisnis dibandingkan informasi keuangan konsolidasi. Informasi lini bisnis juga dianggap lebih jujur dan tidak mengandung unsur yang mudah dilakukan manipulasi seperti halnya laba.

Client importance mempunyai pengaruh positif dan signifikan pada volatilitas idiosinkratik, memperoleh nilai koefisien 0,212 dan signifikansi 0,040. Ini berarti semakin tinggi client importance maka semakin tinggi pula volatilitas idiosinkratik. Client importance adalah ketergantungan ekonomi terhadap klien oleh kantor akuntan publik. Fee yang dibayarkan oleh klien dapat mempengaruhi independensi auditor sehingga menyebabkan auditor seakan memiliki ketergantungan kepada kliennya. Lord (1992) menemukan kontribusi pendapatan relatif dari klien ke kantor akuntan publik mempengaruhi penerimaan auditor terhadap posisi pelaporan agresif klien. Client importance merupakan hal yang menarik karena terkait dengan independensi auditor yang merupakan salah satu indikator dalam menentukan mutu jasa audit dan untuk meminimalisir adanya insentif keuangan serta sosial yang diterima oleh auditor. Su et al. (2016) memperlihatkan client importance berhubungan positif secara signifikan dengan volatilitas idiosinkratik harga saham artinya semakin kantor akuntan publik 
tergantung kepada klien tertentu akan menyebabkan kualitas audit semakin rendah dan investor yang mengambil informasi dari laporan keuangan yang diaudit akan menilai rendah perusahaan sehingga akan memicu reaksi harga saham dengan demikian volatilitas idiosinkratik harga saham menjadi lebih kecil.

\section{SIMPULAN}

Client importance mempunyai pengaruh positif yang signifikan terhadap volatilitas idiosinkratik dan sebaliknya kompleksitas perusahaan mempunyai pengaruh negatif yang signifikan terhadap volatilitas idiosinkratik. Ini berarti informasi lini bisnis dan faktor terkait auditor menjadi signal bagi investor yang mengambil informasi dari laporan keuangan yang diaudit. Ini menunjukkan penting bagi perusahaan untuk memperhatikan setiap penyajian informasi pada laporan keuangan terutama terkait dengan lini bisnis dan informasi terkait biaya monitoring dari auditor. Pada penelitian yang akan datang perlu dilakukan penelitian yang juga melibatkan informasi dari laba rugi, arus kas perusahaan sebagai informasi yang lebih awal dipelajari investor.

\section{REFERENSI}

Baldwin, B. A. (1984). Segment earnings disclosure and the ability of security analysts to forecast earnings per share. Accounting review, 376-389. doi:10.2307/246700

Chen, Q., Goldstein, I., \& Jiang, W. (2006). Price informativeness and investment sensitivity to stock price. The Review of Financial Studies, 20(3), 619-650. doi:10.1093/rfs/hhl024

Collins, D. W. (1976). Predicting earnings with sub-entity data: Some further evidence. Journal of Accounting Research, 14(1), 163-177. doi: $10.2307 / 2490463$

Durnev, A., Li, K., Mørck, R., \& Yeung, B. (2004). Capital markets and capital allocation: Implications for economies in transition. Economics of Transition, 12(4), 593-634. doi:10.1111/j.0967-0750.2004.00196.x

Ferreira, M. A., \& Laux, P. A. (2007). Corporate governance, idiosyncratic risk, and information flow. The Journal of Finance, 62(2), 951-989. doi:10.1111/j.15406261.2007.01228.x

Foucault, T., Hombert, J., \& Roşu, I. (2016). News trading and speed. The Journal of Finance, 71(1), 335-382. doi:10.1111/jofi.12302

Haggard, K. S., Martin, X., \& Pereira, R. (2008). Does voluntary disclosure improve stock price informativeness? Financial Management, 37(4), 747-768. doi:10.2307/20486678

Hutton, A. P., Marcus, A. J., \& Tehranian, H. (2009). Opaque financial reports, R2, and crash risk. Journal of Financial Economics, 94(1), 67-86. doi:10.1016/j.jfineco.2008.10.003

Jin, L., \& Myers, S. C. (2006). R2 around the world: New theory and new tests. Journal of Financial Economics, 79(2), 257-292. doi:10.1016/j.jfineco.2004.11.003

Kwan, S. H. (1996). Firm-specific information and the correlation between individual stocks and bonds. Journal of Financial Economics, 40(1), 63-80. doi:10.1016/0304-405x(95)00836-4 
Lee, D. W., \& Liu, M. H. (2011). Does more information in stock price lead to greater or smaller idiosyncratic return volatility? Journal of Banking $\mathcal{E}$ Finance, 35(6), 1563-1580. doi:10.1016/j.jbankfin.2010.11.002

Lintner, J. (1965). The valuation of risk assets and the selection of risky investment in stock portfolios and capital budgets. The Review of Economics and Statistics, 47(1), 13-37. doi:10.2307/1924119

Lobo, G. J., Kwon, S. S., \& Ndubizu, G. A. (1998). The impact of SFAS No. 14 segment information on price variability and earnings forecast accuracy. Journal of Business Finance $\mathcal{E}$ Accounting, 25(7-8), 969-985. doi:10.1111/14685957.00221

Lord, A. T. (1992). Pressure: A methodological consideration for behavioral research in auditing. Auditing, 11(2), 90.

Lu, T., \& Sapra, H. (2009). Auditor conservatism and investment efficiency. The Accounting Review, 84(6), 1933-1958. doi:10.2308/accr.2009.84.6.1933

Malkiel, B. G. (1989). Is the stock market efficient? Science, 243(4896), 1313-1318. doi:10.1126/science.243.4896.1313

Markowitz, H. (1952). Portfolio selection. The Journal of Finance, 7(1), 77-91. doi:10.1111/j.1540-6261.1952.tb01525.x

Morck, R., Yeung, B., \& Yu, W. (2000). The information content of stock markets: why do emerging markets have synchronous stock price movements? Journal of Financial Economics, 58(1-2), 215-260. doi:10.1016/S0304405x(00)00071-4

Roll, R. (1988). R2. The Journal of Finance, 43(3), 541-566. doi:10.1111/j.15406261.1988.tb04591.x

Ronen, J., \& Livnat, J. (1981). Incentives for segment reporting. Journal of Accounting Research, 19(2), 459-481. doi:10.2307/2490875

Sharpe, W. F. (1964). Capital asset prices: A theory of market equilibrium under conditions of risk. The Journal of Finance, 19(3), 425-442. doi:10.2307/2977928

Shleifer, A. (2000). Inefficient markets: An introduction to behavioural finance: OUP Oxford.

Su, L., Zhao, X., \& Zhou, G. (2016). Auditor Tenure and Stock Price Idiosyncratic Volatility: The Moderating Role of Industry Specialization. AUDITING: A Journal of Practice E Theory, 35(2), 147-166. doi:10.2308/ajpt-51256

Tan, M., \& Liu, B. (2016). CEO's managerial power, board committee memberships and idiosyncratic volatility. International Review of Financial Analysis, 48, 2130. doi:10.1016/j.irfa.2016.09.003

Veldkamp, L. L. (2006). Information markets and the comovement of asset prices. The Review of Economic Studies, 73(3), 823-845. doi:10.1111/j.1467937x.2006.00397.x

Wurgler, J. (2000). Financial markets and the allocation of capital. Journal of Financial Economics, 58(1-2), 187-214. doi:10.1016/S0304-405x(00)00070-2 